FILOZOFSKA KRITIKA

KAO NADOGRADNJA

PSIHOANALIZE

(ili ako, kad i koliko

filozofija priznaje Frojdovo

nesvesno)

\section{Aleksandar Damjanović}

Klinika za psihijatriju, Klinički centar Srbije, Beograd, Srbija

Medicinski fakultet, Univerzitet u Beogradu, Beograd, Srbija

„Frojd je učinio lošu uslugu svojim fantastičnim pseudo-objašnjenjima (upravo zato što su genijalna)....Frojdovo delo umrlo je zajedno sa njim. Niko danas ne može da se bavi psiboanalizom onako kako je on to činio "

„Podvrgnuti se psihoanalizi unekoliko je slično kao jesti sa drveta saznanja. Saznanje koje na taj način stičemo suočava nas sa novim etičkim problemima, a ništa ne doprinosi njibovom rešavanju“"

Ludvig Vitgenštajn

\section{UVOD}

Istorijska predstava o nastajanju, proizlaženju svih nauka iz filozofije, ne može se u vremenskom smislu shvatiti pojednostavljeno, kao da se radi o jednokratnom procesu koji se zbio neka-

\section{Kratak sadržaj}

Rad razmatra filozofsku kritiku, ali i filozofske dopune (komplementarnosti) Frojdove koncepcije psihoanalize. Posebno se analizira uticaj Vitgenštajnove, Jaspersove i filozofije Merlo-Pontija na Frojdov rad ali i ,spekulativno,, čitanje Frojda od strane pojedinih filozofskih pravaca i njihovih protagonista. Razmatra se i filozofska kritika pojma nesvesno, kao i činjenica da li je psihoanaliza naučna disciplina. Položaj psihoanalize u savremenoj filozofiji je krajnje kontroverzan - od prihvatanja, negiranja, modifikacija pa sve do pokušaja revalorizacija iuvođenja nove filozofskopsihološke epistemologije.

Ključne reči; filozofija, psihoanaliza, kritika, Vitgenštajn, Frojd

da u prošlosti i od tada traje osiguravajući definitivnu razdvojenost ovih disciplina. Naprotiv, motivi, horizonti i pojmovne anticipacije koje se sadrže u filozofiji jednog doba bivaju neprekidno metodološki i sadržinski prisutni i integrisani u problemskom području nauke tog doba. Glavni 'pravci' (Pozitivizam, Marksizam, Egzistencijalizam, Hermeneutika, Fenomenologija, Strukturalizam, Postmodernizam) su nezavisno jedan od drugog uobličili 'spekulativno čitanje Frojda'. Ove rivalske tradicije u recepciji 'Frojdove psihoanalize' obeležile su osnovnu teorijsku klimu savremene filozofije. U izvesnom smislu se može govoriti o konsolidaciji savremene filozofije iz duha Frojdove teorije. Pri tom, ne smemo da zanemarimo okolnost da je Frojdovo učenje izloženo specifičnoj 'politici 
osporavanja' koja je upisana u postkolonijalanu kritiku psihoanalize i feminističko 'flertovanje' s Frojdom [1].

Dijalektički i bidirekcioni odnos psihoanalize i filozofije oduvek je bio prisutan. Može se pre svega ukratko spomenuti da je taj uticaj ponekad korišćen u površne antifilozofske svrhe, kao što je to slučaj kod logičkog pozitiviste Hansa Rajhenbaha (Hans Reicbnebach, 1891-1953), koji, želeći da anihilira svaku filozofiju koja se ne može izraziti matematičkim simbolima i računom verovatnoće, doslovce smatra da psihološka analiza (koja zapravo prerasta i u patografiju) filozofa više otkriva nego analiza njihovih sistema [2]. Svakako da ovaj spoljašnji, anegdotski pristup filozofiji može biti donekle interesantan (navodi se da je Kjerkegor primio strogo puritansko vaspitanje kao neku vrstu samokazne, da je Šopenhauerov otac izvršio samoubistvo u depresiji, da je Niče mrzeo oca i umro u dubokoj demenciji verovatno kao posledica neurosifilisa, da je Hegelova sestra bolovala od shizofrenije, dok su sva tri brata Ludviga Vitgenštajna počinila samoubistvo), ali ovakva "objašnjenja" su redukcionistička i senzacionalistička, nisu esencijalna za razumevanje nečije filozofije, jer autentičnost filozofskih sistema je posledica lucidnih promišljanja a ne posledica (pato)psihologizacije ili skrivenih genetskih korena traducijanizma [3]. Može se tvrditi da je upravo savremena filozofija uspela da univerzalizuje Frojdov diskurs na takav način da je psihoanalitička kultura postala sastavnim delom nove, 'kosmopolitske kulture'. Psihoanaliza nije samo jedan od pojmova koji se neumitno utisnuo u svest savremenosti, već je reč i o poduhvatu sa značajim teorijskim, naučnim i kulturnim fundusom. Sigmund Frojd (Sigmund Freud, 1856-1939), trajno osporavan i revitaliziran utemeljivač psihoanalize, predvideo je nešto od toga u svom često spominjanom tekstu Budućnost jedne iluzije. Frojd jasno potvrđuje značaj psihoanalize i kao naučne metode i kao istorijske vrednosti u proučavanju čoveka. U uverljivostpsihoanalize on polaže toliku izvesnosti da na kraju kaže da, iako ona nije iluzija, bila bi iluzija verovati da možemo negde na drugom mestu dobiti to što namona (psihoanaliza) ne može pružiti [4]. Frojd ne želi da propagira psihologističke i redukcionističke metode sa pozitivističkom konotacijom pri čemu bi lični i socijalni život sveo na psihizam bez dodira sa realnošću. Njegova metoda analize nije dakle isključivo introspektivna, već sveobuhvatna u onome unutar i u onome izvan ljudskog. U odnosu na one koji osporavaju, kao i pobornike, istorijsko mesto psihoanalize, kao i ličnosti samog Frojda ostaje ipak nedovršena rasprava. Od nastavljača Frojdovog opusa, naravno u novim vrednosnim i didaktičkim opcijama neophodno je pomenuti Žak Lakana (Jacques Lacan, 1901-1981). Na Lakanovom terenu psihoanalitičkog čitanja savremenog subjekta, jedna od novosti u odnosu na Frojda jeste uvođenje i intenziviranjekorelacije subjekta sa Simboličkim poretkom, pri čemu se fokusira na istraživanju (nalaženju) njegovog simboličkog i traumatskog poniranja [5]. Iako Lakanova hermeneutika, odbacu- 
je staru psihologiju, ali i savremenu psihologijui klasičnu frojdijansku psihoanalizu, ona originalno tumači odnos subjektovog Innenwelta i Umweltai ne odustaje od filozofije[6]. Lakan se u svom učenju oslanja na niz filozofa a vrlo prominentno izučava i primenjuje egzistencijalno fenomenološku analizu Moris Merlo-Pontija (Maurice Merleau-Ponti, 1908-1961). MerloPonti i Lakan kao da su izmešali sadržaje istog sistema i izašli iz njega, a možda se može reći i da su ga transcendirali. Merlo-Ponti na originalan način tumači filozofski problem telesnosti u svom najpoznatijem delu $\mathrm{Fe}$ nomenologija percepcije. U njemu, kao i kasnije, Merlo-Ponti spaja u jednu ceelinupodručja iz filozofije, psihologije, psihoanalize, teorije govora, fiziologije i drugih područja, stvarajući jednu od prvih komplementarnih knjiga o odnosu telesnosti i subjekta. Smisao ovog traženja na koordinatama psihoanalize i filozofije već je uočio i sam Lakan. U njegovoj knjizi Četiri temeljna pojma psihoanalize on naznačuje ključne pojmove bez kojih se psihoanaliza ne može razumeti[6].To su nesvesno, ponavljanje, prenos i nagon. Ako analiziramo pojam,ponavlianje, Lakan ga tumači krozjedno specifično tumačenje pogleda, odnosno vidljivog. Pogled, u Lakanovom tumačenju, naspram oka kao funkcije nastoji da istraži bit onog što on zoveskopičko polje. Skopički nagon, kao samo jedan od nagona koji se pojavljuje u tom polju za Lakana, specifičan je, jer se najpostojanije nastoji odupretiponoru s kojim se subjekt susreće u odnosu s okolinom. Ono što je zanimljivo jeste da on svoje tumačenje gradi na uvidima iz MerloPontijevog dela Vidlivoi nevidlivo. Analiza ova dva gledišta o viđenju očigledna je razlikaizmeđu Lakana i Merlo-Pontija. Lakan ne želi da se tumačenjem pogleda u psihoanalitičkom ključusuprotstavi gledištu Merlo-Pontija. On naglašava da je Merlo-Ponti u oku prepoznao začetak Platonove tradicije,koja ideju vidi kao voditelja koji je vodi, a taj je voditelj, dakle, okoper se. On tu ukazuje na zanemarenu zavisnost vidioca od vidljivog. Iz ove situacije Lakan uočava ono što on zove shizma oka i pogleda, u kojoj se zapravo identifikuje ono što on zove skopički nagon koji konstituiše i našu svest, a nalazi se na polju vidljivog. Pomoću Merlo-Pontijevih uvida, Lakan želi da izdvoji razliku između subjekta vidljivog i subjekta želje.Psihoanaliza za Lakana se ne konstituiše kao weltanschaung, već se bavi jednom daljom razradom pojma 'subjekt' u svom specifičnom pojmovnom i istorijskom maniru. Ta specifičnost se kreće od razlikovanja mehaničke funkcije oka i dijalektike želje koja se manifestuje u pogledu. Merlo-Ponti je Lakanu bio inspiracija, kao što je već i navedeno, svojom razradom odnosa vidljivog i nevidljivog. Vidljivo predstavlja jednu novu ontološku, optičku perspektivu i jednu specifičnu ontološku moć bića da se konstituše u svetu. Ipak ona za MerloPontija nema određenje psihoanalitičkog značenja, već je reč o moći subjekta da se konstituiše u svetu u odnosu na telo i bitak telesnosti. Telo nije skup funkcija ili, samo deo prostora, već jedan skup značenja i postojanja bitka. Merlo-Ponti je delimično naklonjen 
psihoanalizi. Psihoanalitička tumačenja on vidi kao sugestije, koje ako se ne mogu dokazati, ne mogu se ni eliminisati, on psihoanalizu razume i kao određen vid subjektivizacije koji se ogleda u stvaralačkom osvajanju nas samih, bez konzistentnih zahteva strogosti $[7,8]$.

\section{Da li je psihoanaliza nauka}

Poper (Karl Popper, 1902-1994) nam je poznat, kada su metodološki principi u pitanju, pre svega posvom kriterijumu opovrgliivosti koji, po njegovom mišljenju, jasno razgraničava nauku od metafizike. Dakle, da bi jedna teorija bila naučna, moraju biti zamislive instancekoje je opovrgavaju.One teorije koje su principijelno neoborive jer su postavljenetako da ih nikakvo moguće iskustvo ne može ugroziti, Poper naziva metafizičkim i značajan deo njegovog filozofskog opusa (posebno "Otvoreno društvo i njegovi neprijatelji”) posvećen je kritici upravo takvih teorija koje se žele predstavitikao naučne premda to, prema navedenom kriterijumu, nisu. U svojoj autobiografiji „Traganje bez kraja “ on se priseća presudnog uticaja koji je na njegovu metodologiju odigrala jedna Ajnštajnova (Einstein) izjava,kojom on tvrdi kako je spreman da odbaci svoju teoriju relativnosti ukoliko bi ona na određenim eksperimentima zakazala. „Ovo je jedan stav potpuno različit od dogmatskog stava Marksa, Frojda, Adlera“, piše Poper. „Ukoliko neko postavi naučnu teoriju, moraće poput Ajnštajna da odgovori na pitanje: 'pod kojim uslovimaću priznati da je moja teorija neodrživa?' Drugim rečima, koje ću eventualne činjenice prihvatiti kao pobijanje, odnosno dokaz netačnosti moje teorije? - Bio sam šokiran činjenicom da su marksisti i psihoanalitičari svih pravaca bili u stanju da svaki mogući događaj interpretiraju upravo kao potvrdu svojih teorija“ [9].

Vitgenštajn, (Ludwig Josef Johann Wittgenstein, 1889 -1951), s druge strane, nije bio zastupnik nikakve pozitivne doktrine za njega je filozofija, štaviše, predstavljala aktivnost čiji je cilj konačno oslobođenjeodsvih doktrina. $\mathrm{Na}$ meti njegove kritike,između ostalih, našao se i Frojd. Nit vodilju Frojdove teorije činila je pretpostavka da u psihičkom životu vlada strogi determinizam (kao što to o fizičkom svetu pretpostavljaju prirodne nauke)kojeg ljudi nisu svesni, a zadatak naučnika je u tome da te psihičke zakone otkrije [10], Frojd je verovao da mora postojati jedinstvenoobjašnjenje suštine snevanja (a bio je ubeđen da je do tog objašnjenja I došao: svaki san je ispunjenje želje).Svakako da predstavlja ogromnu eksplanatornu moć jedne teorije, ako joj polaziza rukom da objašnjenja svih pojava jedne oblasti iskustva izvede iz jednog osnovnog principa - to gotovo da je ideal nauke. Kao što Vitgenštajn primećuje, ,izvesne vrste objašnjenja su neodoljivo privlačna (...) ljude je izuzetno privukla objedinjenost te (Frojdove)teorije jednim principom - koji je prihvaćen kao očigledno rešenje" [10]. Značajan nedostatak Frojdove teorije ogleda se u izveštačenosti i neprirodnosti pojedinih objašnjenja koja je tolika, da dovodi u 
pitanje prihvatljivost Frojdove teorije. Iako je Frojd bio „vešt" i „lukav" Vitgenštajn ne smatra da je stvorio nešto revolucionarno i genijalno. On je samo kreator jedne nove mitologije i novog pojmovnog okvira. Nesvesno po njemu nija ništa revolucionarno, Frojd nije stvorio nove regione duše. Ono što Frojd tvrdi o nesvesnom zvuči kao nauka (empirijska hipoteza) ali je zapravo samo sredstvo reprezentacije. U „Plavoj knjizi“ Vitgenštajn piše: „Ideja da postoje nesvesne misli izazvala je revolt kod velikog broja ljudi. Drugi su opet rekli da oni nisu u pravu kada predpostavljaju da postoje jedino svesne misli $i$ da je psihoanaliza otkrila nesvesne misli. Oni koji se protive nesvesnim mislima nisu uočili da se ne protive novootkrivenim psihološkim reakcijama, več načinu na koje su one opisane"[11].

\section{Postoji li nesvesno - tumačenje filozofa Bečkog kruga}

Sa stanovišta filozofije Bečkog kruga, uzmemo li Rudolfa Karnapa ( $R u$ dolf Carnap, 1891 -1970) kao njenog paradigmatčnog predstavnika, pitanje o nesvesnom spadalo bi u takozvana „eksterna“ pitanja, to jest pitanja o prihvatanju određenog pojmovnog okvira. Bez obzira na to što ključni pojmovi psihoanalize - nesvesno, kompleks, simptom i sl. - nemaju direktnu potvrdu u iskustvu, to nije raz$\log$ za njihovo odbacivanje, jer oni igraju ulogu okvira „Reference na nesvesne komplekse u psihologiji ne impliciraju tvrdnju kako se entiteti ovih vrsta javljaju kao neposredno date“
[12]. Okvir, sam po sebi, nikada nije ni istinit ni lažan - on je samo odabrani način, sredstvo kojim će se interpretirati određeni aspekt iskustva. Stoga, govor o nesvesnom ne bi smeo biti odbačen a priori. Prihvatanje okvira ne zahteva nikakvo teoretsko opravdanje, jer ono je „praktična odluka koja se tiče strukture našeg jezika. Moramo napraviti izbor da li prihvatamo i koristimo forme izražavanja za okvir koji je u pitanju, ili to ne činimo (...) Prihvatanje se ne može procenjivati kao istinito ili lažno zato što ono nije tvrdnja“. Za razliku od „eksternih“, „interna“ pitanja podležu proveri: pošto je određeni okvir prihvaćen, primenom principa verifikacije određeni iskazi unutar okvira se utvrđuju kao istiniti a drugi kao lažni - „interna pitanja su ovde, uopšte, empirijskapitanja na koje treba odgovoriti empirijskim istraživanjima. Sa druge strane, eksterna pitanja (...) su pseudo-pitanja“"[12].

Kojim kriterijumima se, onda, rukovodimo u odlučivanju za ili protiv prihvatanja novog okvira? Karnapov odgovor na ovo pitanje krajnje je pragmatičan: „U prihvatanju ili odbacivanju (...) bilo kojih lingvističkih formi, u bilo kojoj grani nauke,na kraju će odlučiti njihova uspešnost kao instrumenata, srazmera postignutih rezultata $\mathrm{i}$ količine i kompleksnosti napora koji su potrebni (...) Dopustimo slobodu onima koji rade u nekom specijalnom području istraživanja da koriste bilo koju formu izražavanja, koja izgleda da im koristi; sam rad na tom polju će pre ili kasnije dovesti do odbacivanja onih formi koje nemaju korisnu funkciju“. Smatra u istom delu Karnap ko- 
ji je, kuriozuma radi, sam prošao kroz niz psihoanalitičkih terapijskih seansi. Dakle: teorija o nesvesnom - kao i bilo koja druga - načelno je dopuštena, a tek rezultat njenog razvoja - mera njenog uspeha u suočavanju sa problemima - presudiće o tome da li ona treba i da opstane. Beskorisne, neplodne teorije vreme ćesamo izbrisati sa naučne scene. Psihoanaliza se kao teorija, može dovesti u pitanje ako se dokaže da narušava bazične principe logike $\mathrm{i}$ metodologije. $\mathrm{Na}$ primer, ako neki principi psihoanalize krše princip neprotivrečnosti, koji predstavlja jedan od osnovnih logičkih principa, onda oni time krše i principe same racionalnosti, pa a fortiori i principe nauke; a široka prihvaćenost rešenja psiholoških problema sugerisanih psihoanalizom, tada se lako može objasniti posledicom ljudske iracionalnosti i sklonosti ubeđivanju. Vitgenštajn ističe da se reč "nesvesno“ u svakodnevnom jeziku koristi kao pridev i označava sadržaje koji nisu prisutni u svesti. Frojd je prvo poimeničio ovaj pridev a zatim predpostavio da tako dobijena imenica predstavlja ime nove i neistražene oblasti nastanjene entitetima koji ne samo da nisu prisutni u svesnom, već i da to ne mogu da budu usled potiskivanja. Tek primenom metoda psihoanalize nesvesne misli i želje postaju svesne. Vitgenštajn ukazuje da nesvesno kao fundamentalni termin psihoanalize ima svoje značenje jedino unutar iskaza psihoanalitičkog diskursa a da je značenje ovih iskaza određeno načinom njihove verifikacije. S obzirom da se tvrđenja psihoanalitičara smatraju verifikovanim onda kada ih klijent koji se podvrgava psihoanalizi prizna kao ispravna objašnjenja svog ponašanja sledi da je reči da je izvesna osoba imala nesvesne misli ili želje kada je postupila na određeni način ne znači ništa drugo nego reći da će ona biti sklona da prihvati naknadnu rekonstrukciju tog događaja koju joj ponudi analitičar. Svi iskazi o nesvesnom mogu se redukovati, prema Vitgenštajnu, na iskaze o ovakvom prepoznavanju post factum njima se ne tvrdi da su određene „duševne sile“ u pacijentu bile uzročno aktivne u toku samog analiziranog postupka kao što je verovao Frojd jer bi u tom slučaju istinitost ovakvih postupaka morala da se proveri na sasvim drugačiji način.

\section{VITGENŠTAJN VS. FROJD}

Za Vitgenštajna filozofija je aktivnost. Glavni zadatak filozofije treba da bude jasno razlučivanje mišljivog od nemišljivog, ona treba da ograniči nemišljivo iznutra pomoću mišljivog i time ukaže na neizrecivo. Jasno prikazujući neizrecivo sama filozofija će značiti neizrecivo. Nijedna prirodno-naučna teorija ne menja ništa u strukturi i obliku filozofskih problema. Sve one mogu imati i obično imaju filozofski interpretciju, ali to za samu filozofiju ništa ne znači. Darvinova teorija ne utiče na filozofiju više nego neka druga naučna teorija; one su od bitnog značaja samo za područje prirodnih nauka. Vitgenštajnov stav prema Frojdu bio je ambivalentan $-\mathrm{s}$ jedne strane ga je visoko cenio (i jedno vreme čak govorio o sebi kao o „Frojdovom sledbeniku" [13] ali je istovremeno sma- 
trao da Frojdovo učenje lako može da zavede na pogrešan putukoliko se shvati bukvalno. Odnos prema Frojdu uočava se u pismu koje Vitgenštajn šalje Normanu Malkomu (Norman Malcolm): "I ja sam takođe bio veoma impresioniran kada sam prvi put čitao Frojda. On je izuzetan-kod njega naravno ima puno sumnjivog razmišljanja a njegov šarm i privlačnost predmeta koji razmatra toliko su veliki da lako možeš da se prevariš. On uvek ističe koliko je jak duševni otpor, koliko su snažne predrasude protiv psiboanalize. Ali nikada ne kaže da ta ideja poseduje za liude ogroman šarm kao uostalom $i$ za samoga Frojda. Možda postoje snažne predrasude protiv razotkrivanja nečeg nedoličnog ali ponekad je to beskrajno privlačnije nego što je odbojno. Osim ako ne razmišljaš vrlo jasno psihoanaliza je vrlo opasna $i$ nepoštena praksa $i$ nema kraja njenim lošim posledicama, a za uzvrat je učinila malo dobrog".

Filozofija je za Vitgenštajna - kao i psihoanaliza za Frojda - bila sredstvo borbe protiv problema, ali za razliku od Frojda on nije razvio nikakvu tehničku terminologiju, niti je težio utemeljenju određene škole i to zbog toga jer je smatrao da je pogrešno uzvisiti jednu određenu vrstu diskursa - makar on bio naučni ili medicinski - kao obrazac za rešenje suih problema. Problemi mogu biti raznovrsni i nema nikakvog osnova za pretpostavku da se svi mogu rešiti po istom ključu. Cilj filozofske terapije je zadobijanje jasnog uvida u ono što nas muči, ali taj uvid nikada nije zagarantovan rutinskom primenom određene tehnike. Čak iako psihijatar jasno vidi problem pacijenta, on ga ne može rešiti umesto pacijenta -kao što duhovito kaže Vitgenštajn, „Niko ne može misliti neku misao za mene, istokao što mi niko umesto mene ne može staviti šešir" [14]. Za Vitgenštajna terapija je mišljenje koje dele dvoje, i u kojem je hrabrost da se ispadne glup i neznalica mnogo važnija od znanja. Suština Vitgenštajnovog pristupa sastoji se u rasvetljavanju istog problema iz različitih uglova, sve dok jedan aspekt viđenja ne „upali“ i ne rasprši problem time što ga učini jasnim - jer „filozof tretira jedno pitanje, kao što se tretira neka bolest“" smatra Vitgenštajn, a krajnji cilj filozofske kure je potpuno iščeznuće problema. Smer u njihovom rešavanju traži se bez vođstva doktrine i Vitgenšatajn je, shvatajući filozofiranje prvenstveno dijaloški, upozoravao na čuvanjeod iskušenja umirujućih objašnjenja, glasa koji se traži izvan razgovora, kojibi upravljao mišlju i ponašanjem. Vitgenštajn je Frojdu zapravo najviše zamerao da nije adekvatno razdvajao značenje uzroka i razloga „Kad se smejemo a ne znamo zašto Frojd je turdio da to možemo da odgonetnemo posredstvom psiboanalize. Ovde uočavamo da su uzroci pobrkani sa razlozima. Biti načisto zašto se smeješ nije isto što $i$ biti načisto sa uzrocima. $\mathrm{Ka}$ da bi to bio slučaj tada slaganje sa analizom vica koja je data kao objašnjenje toga zašto se smeješ ne bi bio način da to otkriješ.Pretpostavlja se da slaganje (analizirane) osobe pokazuje da je analiza bila uspešna. Nema ničega što bi tome odgovaralo u fizici. Naravno možemo da navedemo uzroke smeha, 
ali da li su to zaista uzroci ne pokazuje se u tome što se (analizirana) osoba slaže da jesu. Uzroci se otkrivaju eksperimentalnim putem. Psihoanalitički način utvrđivanja zašto se neko smeje analogan je estetskom istraživanju. Jer (kriterijumi) ispravnosti estetske analize mora biti to da se osoba kojoj je ponuđena analiza slaže sa njom. Razlika između razloga i uzroka pokazuje se $u$ sledećem: esencijalni deo istraživanja razloga jeste da se osoba sa tim složi, dok se istraživanja uzroka obavljaju eksperimentalno. Ono sa čime se pacijent slaže ne može biti hipoteza o uzor$k u$ njegovog smeha već jedino da je to $i$ bio razlog zašto se smejao. Naravno osoba koja se slaže da je to bio razlog smeh nije bila svesna da je to bio raz$\log$ (za njeno ponašanje) $u$ to vreme ali reći da je to podsvesni razlog samo je način izražavanja".

\section{Frenk Kjofi}

Frenk Kjofi (Frank Cioffi, 19282012) ističe da je nerazlikovanje uzroka i razloga zapravo konstitutivni deo Frojdove teorije, a ne neki izgredni propust. Stapanje ovih različitih pojmova i jedan omogućava Frojdu da uvek bude u pravu: kada se psihoanalizom otkriju nesvesni uzroci i razlozi nečijeg ponašanja slaganje analizirane osobe potvrđuje ispravnost analize jer je reč o razlozima: međutim neslaganje analizirane osobe sa predloženom analizom ne opovrgava ispravnost analize pošto su istovremeno to i uzroci a analizirana osoba ne mora biti u stanju da prepozna uzroke svog ponašanja. Dakle nenaučni i mitološki karakter psi- hoanalize proizilazi iz toga što je Frojd revidirao značenje reči „uzrok“, upotrebljavajući je čas u tradicionalnom značenju onoga što kauzalno određuje nečije ponašanje a čas da njom označi razloge koji racionalizuju to ponašanje i pružaju neku vrstu teleološkog objašnjenja.

\section{Ipak pro et contra}

Iako prema Vitgenštajnu psihoanaliza nije nauka to joj ne umanjuje značaj - stvaranje novih pojmovnih okvira jednako je važno kao i formulisanje novih empirijskih hipoteza. Čak je i na jednom svom predavanju Vitgenštajn psihoanalizu nazvao „božanstvenom reprezentacijom“. Njegovo shvatanje filozofske analize ima sličnosti sa psihoanalizom: kao i psihoanaliza tako i analiza našeg svakodnevnog jezima ima terapeutsko dejstvo i predstavlja terapeutski metod, dok nam prva pomaže da se oslobodimo neuroza i anksioznosti, druga nam pokazuje izlaz iz brojnih problema i pseudoproblema koji nas često muče i zbunjuju. Ipak krajem tridesetih godina dvadesetog veka, Vitgenštajn je mislio da počne ozbiljno da se bavi psihoanalitičkom praksom (za koju je smatrao da ima izraziti talenat) jer je to smatrao logičkim nastavkom svojih filozofskih istraživanja.

\section{Kriterijum naučnosti: opovrgljivost}

Jedan odglavnih razloga ne prihvatanja istinitosti Frojdovog učenja je u tome, što njene ključne postavke često ostaju u sferi pukih hipoteza koje se ne 
mogu opovrgnuti, ali ni potvrditi nikakvim (mogućim) iskustvom - osobina koja ih čini, poperovskim žargonom rečeno, metafizičkim (kao suprotstavljene naučnim). Poput solipsizma ili idealizma i kod psihoanlize važi tvrdnja - nijedna činjenica ne može da se opravda niti opovrgne - odnosno psihoanaliza nije nauka per se kako to jasno tvrdi Karl Poper. Slično je i sa Frojdovom analizom snova. To, da su ljudi skloni verovanju da snovi imaju neko skriveno značenje, primećuje i Vitgenštajn: „Za snove je karakteristično da se snevaču često čini da oni zahtevaju tumačenje (...). Postoji nešto u predstavama iz snova što poseduje izvesnu sličnost sa znacima nekog jezika. Sličnost koju bi mogao da ima niz oznaka na papiru ili u pesku. Među njima ne mora da se nalazi nijedna oznaka koju smo prepoznali kao konvencionalni znak iz nekog alfabeta koji poznajemo, a, ipak, mogli bismo da imamo snažan osećaj da te oznake moraju biti nekakav jezik: da nešto znače“ [15]. Frojdov osnovni stav da je san ispunjenje potisnutih želja snevača nije empirijska hipoteza, jer tad bi on bio opovrgnut brojnim primerima snova u kojima se npr. izražava potiskivanje straha a ne želja. Frojd je naizgled ovaj problem razrešio uvođenjem koncepta manifestnog i latentnog sna (pri čemu latentni deo sna uvek sadrži potisnutu želju ma kakav je sadržaj manifestnog sna). Ovim konceptom Frojd je zapravo mogao da isključi svaku negaciju svoje teorije. Frojd čini jedan hrabar korak i kao radnu hipotezu svoje teorije uzima, zdravo za gotovo, da mora biti da je san „... izopačena zamena za nešto drugo, nesvesno, i zadatak tumačenja snova je da nađe to nesvesno“ [16]. Modifikujući svoju teoriju tako da njome bude moguća uspešna analiza svih vrsta snova, Frojd je "poboljšava“ sledećom formulom: san je prikriveno ispunjenje jedne potisnute, suzbijene želje. Osim toga što čini stvari još više neodređenim, dopuštajući da sve što ne liči na ispunjenje želje može ipak biti prikriveno ispunjenje i da ono što nije prepoznato kao želja ipak može biti potisnuta želja, ova formula ima i jedan nedostatak logičke prirode, naime taj, da određena želja ne može biti ispunjena time što će se, umesto nje, zadovoljiti neka druga koja treba da predstavlja njenu zamenu. Frojd po Vitgenštajnu nije stvorio naučnu teoriju snova već samo nov sistem njihove reprezentacije; prilikom tumačenja snevač u izvesnom smislu iznova sanja san ali u okruženju u kome su izmenjeni njegovi aspekti. Teza da je svaki san samo ispunjenje želje snevača nije suština niti razrešenje već samo gramatičko pravilo; to pravilo treba da omogući prihvatanje i razrešenje simbola sna koje je Frojd smislio kao pravilo svoje teorije. Vitgenštajn je smatrao da podjednako treba prihvatiti i koncept potisnutog straha kao sadržaja sna ali to bi zahtevalo od Frojda građenje novg pojmovnog aparata i nove hermeneutike $[17,18]$.

\section{Karl Jaspers i kritika psihoanalize}

Karl Jaspers (Karl Jaspers, 18831969) je svojom "Opštom psihopatologijom” svakako učinio grandioznu (r)evoluciju u oblasti psihijatrije. Iako 
primarno psihijatar njegova velika ljubav prema filozofiji odvela ga je na katedru filozofije na Univerzitetu Hajdelberg. Jaspers je bio jedan od ideološki prominentnijih kritičara Frojdove konceptualne postavke psihoanalize kao i metodologije same psihoterapije. Najpre smatrao je da psihoanalitički pokret ima status sekte jer se u njegove redove može ući samo posredstvom uvodnog rituala inicijacije odnosno obavezne didaktičke analize. Vrlo oštro Jaspers je smatrao da psihoanaliza ne zavređuje status univerzitetske discipline, jer metoda koja se ne može ispitati racionalno već samo posredstvom prethodne inicijacije kandidata (čime počinje preobražaj istog) to i ne zaslužuje.Iako je analizu kritikovao i zbog autoritarnosti, kao i svojevrsnog redukcionizma, Jaspers smatra da je pogrešna njena namera da se nametne kao naučna disciplina a ne kao medicinska i terapeutska. Uvodeći koncepcije objašnjavajuć i razumevajuće psihologije Jaspers smatra da Frojdova psihoanaliza ulazi u konfuznu ulogu u odnosu na ove dve kategorije. Objašnjavajuća psihologija objašnjava psihičke fenomene njihovim uzrocima (kao kad bi nauka utvrđivala kauzalne serije u psihičkoj oblasti). Razumevajuća psihologija čini suprotno - ona shvata psihičke fenomene po njihovom smislu, polazeći od smisla koje oni imaju za posmatrani subjekt. Prema Heršovoj čin razumevajuće psihologije se ostvaruje kada terapeut uspe da proživi, da iznutra sam odigra nameru subjekta, što mu omogućava da objektivno shvati redosled njegovih stanja svesti [19]. Dakle u slučaju objašnjava- juće psihologije psihijatar se oslanja na neki uzrok- a uzrok nema "smisla", on samo produkuje neku posledicu, u drugom slučaju (razumevajuće psihologije), polazi se od smisla za kojim teži neki subject, ta se težnja prihvata in a taj način se razume šta se dogodilo u psihizmu subjekta. Konfuzija između ova dva postupka dovodi kod Frojda da je on verovao da primenjuje metodu objašnjavajuće psihologije. Verovao je da u psihičkoj oblasti stremi istraživanjima koja se bazirana na naučnoj metodologiji prirodnih nauka, alu u stvari, Frojd je prema Jaspersu primenjivao koncepcije razumevajuće psihologije. Za Jaspersa jedna od presudnih zabluda Frojda je izrada takvog obrasca objašnjenja psihizma koje važi za sve, odnosno konstrukcija i razrada celokupne teorije duševnog života. Međutim Jaspers smatra da je izgradnja objašnjenja koja važe za sve moguća jedino po uzoru prirodnih nauka. Samo iz takvih objašnjenja (objektivnih sa naučnim vrednostima) mogu da poteknu teorije ali ne i razumevanje. Razlog je zato što razumeti znači oponašati intencionalni proces drugog subjekta. Pošto uvek mislimo na individualno biće to ne opravdava prelaz na teoriju opštosti.Frojd zanemaruje razliku između „uzroka i smisla“, čineći redukciju koja mu je omogućila da u okviru svog panpsihizma stvori mali broj jednostavnih modela. Govoreći o Edipovom kompleksu, seksualnosti, potiskivanju, snovima, signalnoj anksioznosti nastaje monotonija, pa čak i tendencija ka vulgarizaciji [19]. Frojd prerušava razumevajuće procese, pod krinku stalnog pribegavanja objašnja- 
vajućim procesima, pri čemu taj proces rađa dosadu. Analitičar je „svemoćan“, pronicljiv, lako i elegantno nudi svoje interpretacije. Laička analiza se primenjuje u muzici, poeziji slikarstvu svodeći realnost na nekoliko shema i trikova. Jaspers podvlači delatnost psihoanalize podložnoj lakoj vulgarizaciji. Jaspers ipak smatra da kada bi psihoanaliza bila samo jedna od teorija među drugima bez isključivosti, mogao bi i njen teorijsko-kliničkio doprinos biti plodan i nepretenciozan. Potenciranje frojdijanskog kauzalnog, objašnjavajućeg postupka može značajno da ugrozi egzistencijalni smisao, slobodu i odgovornost subjekta.Frojdova psihoanaliza treba da omogući slobodu pacijenta, da ga samostalno, bez suvišnih sugestija dovede do lucidnih odgovora koji treba da uklone sve prepreke na putu ka njegovoj slobodi.

\section{Zaključak}

Filozofska kritika, ali i iznalaženje filozofskih komplementarnosti u odnosu na Frojdove koncepcije psihoanalize utiču na „novo dešifrovanje Frojda“. Uticaj Vitgenštajnove „filozofije, Jaspersa, Merlo-Pontija, Lakana na Frojdov rad kao i „spekulativno, čitanje Frojda od strane pojedinih filozofskih pravaca i njihovih protagonista (pozitivizma, marksizma, egzistencijalizma, hermeneutike, itd.) osnažili su čitav niz kritičko-nadopunjujućih, epigonskih ali i originalnih diskursa. Ove rivalske tradicije u recepciji 'Frojdove psihoanalize' obeležile su osnovnu teorijsku klimu savremene filozofije. Položaj psihoanalize u savremenoj filozofiji je krajnje kontroverzan -od ponekad nekritičnog prihvatanja, preko bezobzirnog negiranja, plauzabilnih modifikacija pa sve do pokušaja revalorizacija-revitalizacije i uvođenja kako novih epistemoloških obrazaca tako i do postmoderne radoznalosti kao uslova za konstituisanje možda jedne nove psihoanalize. Ili možda da ponovo redefinišemo: psihoanaliza onako kako to pokušava Buvres (Jacques Bouvresse):" možda nije naučna, ali ipak predstavlja ono najnaučnije, ili $u$ svakom slučaju, ono najuverlivije čemu se možemo nadati, s obzirom na prirodu tih fenomena ". Ono što je ipak i u ovom savremenom trenutku izvesno to je da Frojd nije želeo da propagira psihologističke i redukcionističke metode sa pozitivističkom konotacijom pri čemu bi lični i socijalni život sveo na psihizam bez dodira sa realnošću. Njegova metoda analize nije dakle isključivo introspektivna, već sveobuhvatna u onome unutar i u onome izvan ljudskog. U odnosu na one koji osporavaju, kao i pobornike, istorijsko mesto psihoanalize, kao i ličnosti samog Frojda ostaju ipak nedovršena rasprava i mogućnost beskonačne analize. 
PHILOSOPHICAL

CRITICISM AS A

UPGRADE OF

PSYCHOANALYSIS

(or if, when and how much

philosophy recognizes

Freud's unconscious)

\section{Aleksandar Damjanović}

School of Medicine, University of

Belgrade, Belgrade, Serbia

Clinic for Psychiatry Clinical Center of

Serbia, Belgrade, Serbia

\section{Short summary}

The paper examines the philosophical criticism, but also philosophical supplement (complementarity) Freud's conception of psychoanalysis. In particular, we analyze the influence of Wittgenstein , Jaspers and philosophy of Merlo - Ponty on Freud's work but also “ speculative " read Freud by certain philosophical trends and their protagonista. This paper also considers philosophical critique of the notion of the unconscious, and the factwhether psychoanalysis scientific disciplines. Location of psychoanalysis in contemporary philosophy is extremely controversial from acceptance, denial, modification and all attempts to revaluation and the introduction of new philosophical and psychological epistemology

Keywords: philosophy, psychoanalysis, criticism, Wittgenstein, Freud 


\section{Literatura:}

1. Savić O. Kurs Filozofija i Frojd. Beograd; 2012.

2. Rajhenbah H. Rađanje naučne filozofije. Beograd. Nolit; 1964.

3. Drakulić B. Filozofski koreni psihoanalitičke etike Psihijat dan 2010; 42(1): 37-49.

4. Hasnaš S. Psihoanaliza - između filozofije i pozitivizma psihologizacije. Filozofska istraživanja 2007; 27(1):21-6.

5. Lakan Ž. Spisi, Beograd.Prosveta; 1983.

6. Lakan Ž. Četiri osnovna pojma psihoanalize. Zagreb. Naprijed; 1986.

7. Merlo-Ponti M. Oko i duh. Beograd. Vuk Karadžić; 1968.

8. Merlo-Ponti M. Fenomenologija percepcije. Sarajevo. Veselin Masleša; 1990.

9. Popper K. Science, Pseudo-Science and Falsificationism. In: Popper K, editor. Conjectures and Refutations: The Growth of Scientific Knowledge. London: Routledge; 2002. pp. 43-50.

10. Vitgenštajn L. Predavanja i razgovori o estetici, psihologiji i religioznom verovanju. Beograd. Clio; 2008.

11. Sluga S. Ludwig Wittgenstein: Life and Work - An Introduction. In: Sluga H, Stern DG, editors. The Cambridge Companion to Wittgenstein. Cambridge: Cambridge University Press; 2006. p. 5.

12. Karnap R. Empirizam, semantika i ontologija. Beograd. III program; 1971.
13. Vitgenštajn L. Predavanja i razgovori o estetici, psihologiji i religioznom verovanju. Beograd. Clio; 2008.

14. Heaton JM. Wittgenstein i psihoanaliza. Zagreb. Jesenski i Turk; 2001.

15. Wittgenstein L. Culture and Value. Oxford. Blackwell; 1998.

16. Vitgenštajn L. Filozofska istraživanja. Beograd. Nolit; 1969.

17. Vitgenštajn L. Predavanja i razgovori o estetici, psihologiji i religioznom verovanju. Beograd. Clio; 2008.

18. Kanački N. Metafizika nesvesnog - filozofska kritika Frojdovog učenja. Theoria 2009; 52:65-76.

19. Herš Ž. Istorija filozofije: filozofsko čuđenje. Novi Sad. Svetovi; 1998.

Aleksandar DAMJANOVIĆ

Klinika za psihijatriju, Klinički centar Srbije

Pasterova 2, 11000 Beograd, Srbija

Tel: + 381 (0) 668300840

E mail: damal64@yahoo.com 